\title{
Groundwater Quality Assessment in a University Sub-Urban Community in Delta State, Nigeria: Part A-Physicochemical Analysis
}

\section{OWAMAH, HI}

\author{
Department of Civil Engineering, Faculty of Engineering, Delta State University, PMB1, Abraka, Oleh Campus, Delta State, Nigeria \\ Email: owamah.hilary@gmail.com; hiowamah@delsu.edu.ng
} Tel: +2348035705814

\begin{abstract}
This study provides detailed scientific information on the physicochemical properties of drinking water from groundwater in a Nigerian university sub-urban community. Water samples from boreholes (BHs) and handdrawn wells (HDWs) in the community were collected and analyzed for their biological and physicochemical parameters, and the metals from July 2016 to January 2017 for wet and dry seasons. Results obtained, showed that the physicochemical factors complied with the World Health Organization (WHO) guidelines, except for $\mathrm{pH}$ being lower in some locations. In the wet and dry seasons, $\mathrm{pH}$ varied from 4.4 to 6.2 and from 4.8 to 6.7 respectively. While the mean value for wet season was 5.7, dry season was 5.9; to give a seasonal mean difference of 0.2.Cd and $\mathrm{Pb}$, in both wells, for many locations, were slightly higher than the prescribed limits. The slight elevated concentrations of $\mathrm{Pb}$ and $\mathrm{Cd}$ could be attributed to oil exploration activities in the study area. The study recommends the provision of improved drinking water in the community.
\end{abstract}

\section{DOI: https://dx.doi.org/10.4314/jasem.v23i1.22}

Copyright: Copyright () 2019 Owamah. This is an open access article distributed under the Creative Commons Attribution License (CCL), which permits unrestricted use, distribution, and reproduction in any medium, provided the original work is properly cited.

Dates: Received: 31 December 2018; Revised: 18 January 2019; Accepted 26 January 2019

Keywords: Groundwater, quality monitoring, contamination, Niger-Delta

The need to regularly monitoring of the quality of groundwater used as drinking water in rural and suburban communities of developing countries cannot be over-emphasized (Owamah et al., 2013; Sojobi, 2016). This is because, inadequate access to potable water and unavailability of reliable information on quality are major contributors to frequent outbreak of pathogenic diseases in the region. Oleh is one of such communities in Nigeria but peculiar in this circumstance as it houses one of the major campuses of the Delta State University, Abraka. The provision of water in Nigeria is constitutionally, the sole function of government. However, the inability of government to meet with the daily demands of water for the people has forced millions of Nigerians to seek alternatives such as drilling of their own boreholes and hand-drawn wells. Inadequate hygiene, poor sanitation and unsafe drinking water cause over one million global annual deaths and about eighty percent of all ailments in developing nations (WHO, 2012). Furthermore, about $50 \%$ of the global number of persons without access to clean water live in subSaharan Africa. At the moment, those who live in the area of study, basically, depend on water from boreholes and hand-drawn wells (groundwater) since there is no pipe-borne water supply. A lot of water wells were installed without adherence to the standards of the supervising ministry thereby leading to compromised water quality. This study was therefore carried out to evaluate the physicochemical parameters of groundwater in a university sub-urban community in Delta State, Nigeria.

\section{MATERIALS AND METHODS}

Study area description: Oleh is the administrative head of the Isoko South Local Government Area (ISLGA), Delta State. The 2016 census of Nigeria put the population of ISLGA at 323,800 and indicates that ISLGA is one of the most populated LGAs in Delta State (NPC, 2018). Oleh community is the most populated of all the communities in the ISLGA. The coordinates of ISLGA is $5.43^{\circ} \mathrm{N}, 6.20^{\circ} \mathrm{E}$ (Fig. 1). ISLGA resides within the tropical rainforest belt and does experience tropical wet and dry climate.

The main economic activities are food crop farming, animal hunting, trading, and artisan and civil service jobs. Oleh has several primary, secondary and a tertiary schools (Faculties of Law, and Engineering of the Delta State University) with Christianity as the predominant religion.

Water Sampling: Sampling of the borehole and handdrawn well waters were carried out using one and half 
(1.5L) capacity high-density PET screw-capped containers from June 01, 2016 to January 31, 2017. Before collection of the actual sample, bottles were washed for three times and thereafter stoppered, labeled, ice-cooled and transported to Jacio Environmental Limited, Effurun, Delta State, Nigeria.

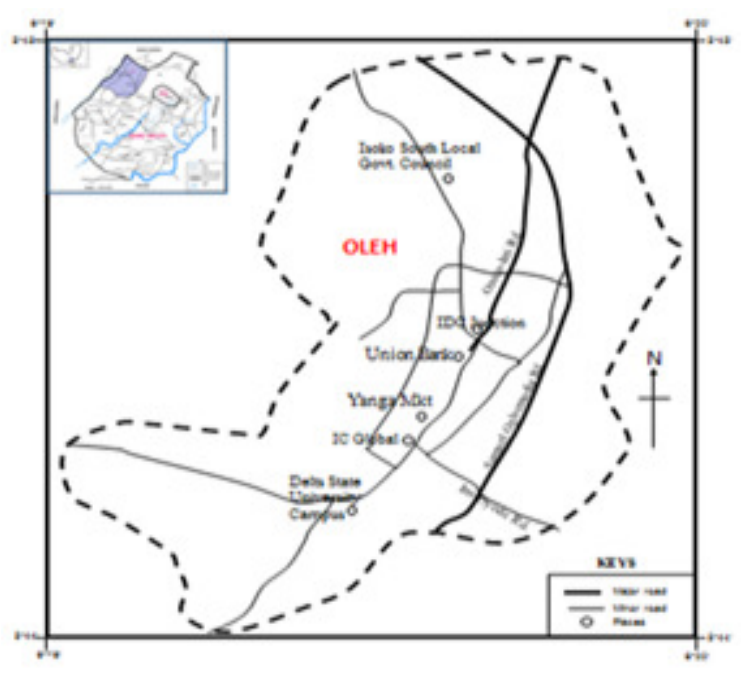

Fig. 1: Map of area of study

Following the work of Owamah et al. (2013), at each sampling point, acidified and non-acidified samples were collected. Autoclave-sterilized bottles were utilized for the collection of samples for bacterial analysis. Eighteen (18) raw water samples, three (3) from each district, were collected every month to amount to a total of eight (108) samples.

Analytical procedures: The parameters; total dissolved solids (VSI 22, India), temperature (HI 98517) , pH (HI 9024-C), electrical conductivity (HI 2315) and salinity (HI 19311) were determined on site using the portable meters. Dissolved oxygen was determined using the prescribed methods in APHA (2012). Through the use of a UV spectrophotometer (DR 2800, HACH, Washington, USA) and adopting ultraviolet spectrophotometer screening method, the anions were determined in accordance with the methods prescribed in APHA (2012). The enumeration of the total coliform bacteria was done according to the guidelines in the analyses of metals was done using atomic absorption spectrophotometer (Sens AA 3000) and in accordance with the methods in APHA (2012).

Statistical analyses: Analyses of data obtained were done using Microsoft Office Excel 2010 software and the Analysis of Variance (ANOVA) statistical tool at $\mathrm{P}<0.005$. The mean and standard deviation of the parameters analyzed were computed for both seasons.
Seasonal variations were then computed as the difference between the wet and the dry season mean values taking the wet season as the reference point.

\section{RESULTS AND DISCUSSION}

Physicochemical parameters: Table 1 and Figs. (2a $2 \mathrm{e})$ show the values of some of the physicochemical parameters obtained in this study. From this study, $\mathrm{pH}$ was found to range from 4.90 to 6.20 in hand-drawn wells and 4.40 to 6.70 in borehole water samples (Table 1). In the wet and dry seasons, $\mathrm{pH}$ varied from 4.4 to 6.2 and from 4.8 to 6.7 respectively. While the mean value for wet season was 5.7 , dry season was 5.9 ; to give a seasonal mean difference of 0.2.

This indicates that the $\mathrm{pH}$ of groundwater sources in the community was fairly constant, season notwithstanding. Granted this, $\mathrm{pH}$ values in the wet season were however, generally, higher than dry season values. This could be associated with the rise of water level during wet seasons, which brings with it some level of dilution. The most acidic values were got from YM district borehole and Old OER district hand-drawn well water samples. For both wet and dry seasons, borehole water samples were found to be more acidic than the hand-dug well water samples.

A maximum $\mathrm{pH}$ of 6.7 was obtained from a borehole in GRA district in the month of September (Table 1, Fig. 2b). The $\mathrm{pH}$ values obtained in this study are similar to reported values for groundwater sources in neighboring Isoko North communities (Owamah et al., 2013). Since the WHO prescription for $\mathrm{pH}$ lies between 6.5 and 8.5, groundwater sources in the community, may need to be treated with lime to raise it to the desired level. Though $\mathrm{pH}$ is not a major health related water quality parameter, low levels of it affect the state of other water quality parameters like solubility of metals and pathogen survival and hence could be capable of causing indirect health problems to humans (Khan et al. 2013).

Drinking water with low $\mathrm{pH}$ could also cause gastrointestinal irritations. The lower than permissible $\mathrm{pH}$ range obtained from the different water sources can be linked to the geological formation in the community (Sojobi, 2016). Similar findings of low $\mathrm{pH}$ values were obtained for groundwater sources of neighboring Isoko North Local Governmental Area communities by Owamah et al. (2013). There was no significant difference ( $\mathrm{p}>$ 0.05 ) in $\mathrm{pH}$ among the sampling sites, wells and across the seasons. The highest EC was obtained from a hand-drawn well (HDW) within FL district $\left(486 \mu \mathrm{S} \mathrm{cm}^{-1}\right)$ in the month of October. 
Table 1. Mean concentrations of some physiochemical parameters of groundwater samples from the study area for wet and dry seasons $(\mathrm{N}=18)$

\begin{tabular}{|c|c|c|c|c|c|c|}
\hline $\begin{array}{l}\text { Location, } \\
\text { Water Source }\end{array}$ & $\mathrm{pH}$ & $\mathrm{EC}\left(\mu \mathrm{S} \mathrm{cm}^{-1}\right)$ & $\begin{array}{c}\mathrm{DO} \\
\left(\mathrm{mg} \mathrm{L}^{-1}\right)\end{array}$ & $\begin{array}{l}\mathrm{BOD}_{5} \\
\left(\mathrm{mg} \mathrm{L}^{-1}\right)\end{array}$ & $\begin{array}{c}\text { Temperature } \\
\left({ }^{\circ} \mathrm{C}\right)\end{array}$ & $\begin{array}{c}\text { TDS } \\
\left(\mathrm{mg} \mathrm{L}^{-1}\right)\end{array}$ \\
\hline w $\mathrm{OER}, \mathrm{BH}$ & $6.1 \pm 0.1$ & $72 \pm 3.3$ & $10 \pm 2.1$ & $7 \pm 1.5$ & $24.6 \pm 0.3$ & $14 \pm 1.4$ \\
\hline "wOER,HDW & $6.2 \pm 0.1$ & $450 \pm 41.5$ & $12 \pm 0.4$ & $6 \pm 0.4$ & $28.4 \pm 0.6$ & $134 \pm 18.0$ \\
\hline d $\mathrm{OER}$,BH & $5.8 \pm 0.0$ & $51 \pm 2.1$ & $10 \pm 2.1$ & $8 \pm 1.3$ & $28.7 \pm 0.7$ & $10 \pm 1.2$ \\
\hline${ }^{\mathrm{d} O E R}$, HDW & $5.9 \pm 0.1$ & $382 \pm 96.5$ & $11 \pm 0.4$ & $6 \pm 0.5$ & $29.6 \pm 0.6$ & $130 \pm 6.1$ \\
\hline w $\mathrm{OEF}, \mathrm{BH}$ & $5.5 \pm 0.2$ & $135 \pm 2.9$ & $12 \pm 1.5$ & $5 \pm 0.4$ & $25.2 \pm 0.8$ & $45 \pm 6.6$ \\
\hline${ }^{\mathrm{w}} \mathrm{EF}, \mathrm{HDW}$ & $5.9 \pm 0.2$ & $138 \pm 5.2$ & $11 \pm 1.0$ & $6 \pm 1.1$ & $28.1 \pm 1.2$ & $43 \pm 6.5$ \\
\hline${ }^{\mathrm{d}} \mathrm{EF}, \mathrm{BH}$ & $4.8 \pm 0.1$ & $287 \pm 4.2$ & $10 \pm 1.5$ & $5 \pm 1.3$ & $25.6 \pm 1.0$ & $40 \pm 3.1$ \\
\hline${ }^{d} E F, H D W$ & $6.1 \pm 0.3$ & $92 \pm 4.1$ & $12 \pm 1.0$ & $6 \pm 0.4$ & $26.3 \pm 0.2$ & $38 \pm 1.2$ \\
\hline w YM,BH & $5.6 \pm 0.2$ & $39 \pm 2.0$ & $13 \pm 1.3$ & $7 \pm 1.3$ & $26.4 \pm 0.8$ & $10 \pm 1.0$ \\
\hline "YM, HDW & $6.2 \pm 0.4$ & $153 \pm 41.1$ & $10 \pm 2.6$ & $5 \pm 0.9$ & $26.6 \pm 0.5$ & $39 \pm 21.1$ \\
\hline d'YM, BH & $5.9 \pm 0.1$ & $43 \pm 7.2$ & $13 \pm 1.3$ & $7 \pm 1.5$ & $27.6 \pm 0.9$ & $12 \pm 3.3$ \\
\hline YM,HDW & $6.2 \pm 0.3$ & $100 \pm 29.5$ & $9 \pm 2.6$ & $6 \pm 1.3$ & $28.0 \pm 0.9$ & $33 \pm 15.4$ \\
\hline w IT,BH & $5.9 \pm 0.1$ & $42 \pm 1.8$ & $9 \pm 2.1$ & $5 \pm 1.1$ & $27.4 \pm 0.8$ & $11 \pm 0.9$ \\
\hline${ }^{\mathrm{w}} \mathrm{IT}, \mathrm{HDW}$ & $6.1 \pm 0.1$ & $141 \pm 2.3$ & $10 \pm 1.7$ & $5 \pm 1.9$ & $27.9 \pm 0.6$ & $53 \pm 2.9$ \\
\hline${ }^{\mathrm{d}} \mathrm{IT}, \mathrm{BH}$ & $5.7 \pm 0.1$ & $35 \pm 1.7$ & $10 \pm 2.1$ & $6 \pm 1.0$ & $27.5 \pm 0.5$ & $12 \pm 0.5$ \\
\hline${ }^{\mathrm{d}} \mathrm{IT}, \mathrm{HDW}$ & $5.9 \pm 0.1$ & $151 \pm 8.7$ & $10 \pm 1.7$ & $4 \pm 1.3$ & $26.4 \pm 0.6$ & $52 \pm 3.2$ \\
\hline${ }^{\mathrm{w}} \mathrm{LF}, \mathrm{BH}$ & $5.6 \pm 0.2$ & $115 \pm 2.4$ & $12 \pm 1.8$ & $6 \pm 0.7$ & $24.2 \pm 1.2$ & $24 \pm 1.8$ \\
\hline${ }^{\mathrm{w}} \mathrm{LF}, \mathrm{HDW}$ & $5.3 \pm 0.1$ & $486 \pm 9.5$ & $13 \pm 0.8$ & $5 \pm 0.2$ & $24.4 \pm 0.7$ & $110 \pm 11.3$ \\
\hline${ }^{\mathrm{d}} \mathrm{LF}, \mathrm{BH}$ & $6.7 \pm 0.6$ & $109 \pm 2.0$ & $9 \pm 1.4$ & $4 \pm 0.6$ & $26.0 \pm 1.2$ & $22 \pm 3.2$ \\
\hline${ }^{\mathrm{d}} \mathrm{LF}, \mathrm{HDW}$ & $5.4 \pm 0.1$ & $320 \pm 45.1$ & $8 \pm 0.7$ & $5 \pm 0.4$ & $25.1 \pm 1.3$ & $111 \pm 3.9$ \\
\hline${ }^{\mathrm{w}} \mathrm{GRA}, \mathrm{BH}$ & $4.4 \pm 0.3$ & $54 \pm 3.3$ & $12 \pm 1.4$ & $7 \pm 0.6$ & $28.3 \pm 0.6$ & $10 \pm 2.4$ \\
\hline${ }^{\mathrm{w}} \mathrm{GRA}, \mathrm{HDW}$ & $5.4 \pm 0.4$ & $246 \pm 21.2$ & $10 \pm 2.3$ & $5 \pm 1.6$ & $24.6 \pm 0.7$ & $55 \pm 2.1$ \\
\hline${ }^{\mathrm{d}} \mathrm{GRA}, \mathrm{BH}$ & $5.8 \pm 0.6$ & $55 \pm 18.0$ & $11 \pm 1.2$ & $4 \pm 1.4$ & $25.2 \pm 0.5$ & $21 \pm 7.0$ \\
\hline${ }^{\mathrm{d}}$ GRA, HDW & $4.9 \pm 0.3$ & $133 \pm 53.1$ & $9 \pm 1.6$ & $3 \pm 0.9$ & $24.2 \pm 0.7$ & $86 \pm 3.1$ \\
\hline
\end{tabular}

$D O=$ dissolved oxygen; EC $=$ Electrical conductivity; Results are expressed as mean \pm standard deviation; ${ }^{w}=$ wet season; ${ }^{d}=d r y$ season

This was closely followed by another HDW at OER district $\left(450 \mu \mathrm{S} \mathrm{cm}^{-1}\right)$ (Table 1). The values are in accordance with the stipulated limit of $1000 \mu \mathrm{S} \mathrm{cm}^{-1}$ by the SON (2007) and the WHO (2006) for drinking water. There was no significant variability $(p>0.05)$ among the different sources, locations and seasons. EC results obtained are consistent with findings from other parts of Nigeria; while a maximum and minimum EC of $500 \pm 41.5 \mu \mathrm{S} \mathrm{cm}^{-1}$ and $75 \pm 3.3 \mu \mathrm{S}$ $\mathrm{cm}^{-1}$ were obtained for neighboring Isoko North LGA communities by Owamah et al. (2013), Dahunsi et al. (2014) obtained $308.33 \pm 1.53 \mu \mathrm{S} \mathrm{cm}^{-1}$ and $22.4 \pm 0.53$ $\mu \mathrm{S} \mathrm{cm}{ }^{-1}$ as maximum and minimum EC for selected communities in Ogun and Lagos States. In all water samples collected, values of TDS obtained were found to be lower than the stipulated maximum value of $500 \mathrm{mgL}^{-1}$ set by the WHO (2005) and the SON (2007) for drinking water. While TDS is a function of the sum total of ions in solution, EC is a function of the ionic activities (LENNTECH, 2016). Mean TDS values obtained for wet and dry seasons are 54 and 52 $\mathrm{mg} \mathrm{L}^{-1}$ respectively, with a seasonal mean variation of $-2 \mathrm{mg} \mathrm{L}^{-1}$ (wet-dry). It ranged from 10 to $134 \mathrm{mg} \mathrm{L}^{-1}$ in the wet season and 12 to $134 \mathrm{mg} \mathrm{L}^{-1}$ in the dry season.

Hand-drawn well water samples from OER district had the maximum dry and wet season TDS of 134 and $130 \mathrm{mg} \mathrm{L}^{-1}$, respectively (Fig. 2e). Compared with borehole water samples (Table 1), water samples from the hand-drawn wells had higher values and this can be linked to the intrusion of runoff into them, following the absence of borehole casings and caps. It could also be the result of soil disturbance within the well during water withdrawals (Mkwate et al, 2017). Similar values of higher TDS for shallow wells were obtained by Dahunsi et al. (2014) for selected communities in the South-Western Nigeria and Owamah et al. (2013) for communities in the neighboring Isoko North Local Government Area.

The seasonal average values for DO are 9 and $8 \mathrm{mg} \mathrm{L}^{-}$ ${ }^{1}$ for wet and dry seasons respectively. It ranged from 10 to $13 \mathrm{mg} \mathrm{L}^{-1}$ for wet season and 10 to $12 \mathrm{mg} \mathrm{L}^{-1}$ for the dry season. Fig. 2c shows the values of DO obtained from boreholes and hand-drawn wells in both seasons. The DO values obtained in the study area are above the WHO (2006) desired value of $4 \mathrm{mg}$ $\mathrm{L}^{-1}$ and hence in order. BOD ranged from 5-7 and 4-8 $\mathrm{mg} \mathrm{L}^{-1}$ for wet and dry seasons, respectively (Fig. 2d). For both seasons, the seasonal mean value is $6 \mathrm{mg} \mathrm{L}^{-1}$ (Table 1). Ademoroti (1996) and Owamah et al. (2013) reported that the maximum allowable $\mathrm{BOD}_{5}$ is $6 \mathrm{mg} \mathrm{L} \mathrm{L}^{-1}$; as higher values mean organic contamination.

Anions: Table 2 contains the average values of the anions gotten in this study. Chloride concentration obtained ranged from 3 to $58 \mathrm{mg} \mathrm{L}^{-1}$ and 5 to $65 \mathrm{mg} \mathrm{L}^{-}$ ${ }^{1}$ for the wet and dry seasons respectively. Seasonal 
mean values of 17 and $13 \mathrm{mg} \mathrm{L}^{-1}$ were recorded for wet and dry seasons, respectively. In line with the report of Egboh and Emeshili (2008) of higher chloride concentrations in wet season for communities in the neighboring Ndokwa East Local Government Area, chloride values obtained were higher in hand-drawn wells and during the wet season.

Table 2. Mean values $\left(\mathrm{mg} \mathrm{L}^{-1}\right)$ of anions of groundwater samples from the study area for wet and dry seasons $(\mathrm{N}=18)$

\begin{tabular}{|c|c|c|c|}
\hline $\begin{array}{l}\text { Location/Water } \\
\text { Source }\end{array}$ & $\mathrm{NO}_{3}^{-}$ & $\mathrm{Cl}^{-}$ & $\mathrm{SO}_{4}{ }^{2-}$ \\
\hline${ }^{\mathrm{w}} \mathrm{OER}, \mathrm{BH}$ & $1 \pm 0.5$ & $4 \pm 0.2$ & $5 \pm 0.1$ \\
\hline${ }^{\mathrm{w}} \mathrm{OER}, \mathrm{HDW}$ & $3 \pm 2.1$ & $58 \pm 3.4$ & $28 \pm 4.8$ \\
\hline d $\mathrm{OER}$,BH & $1 \pm 0.2$ & $5 \pm 1.2$ & $4 \pm 0.6$ \\
\hline${ }^{\mathrm{d}} \mathrm{OER}, \mathrm{HDW}$ & $2 \pm 0.5$ & $33 \pm 14.6$ & $19 \pm 12.0$ \\
\hline${ }^{\mathrm{w}} \mathrm{OEF}, \mathrm{BH}$ & $2 \pm 0.6$ & $4 \pm 0.1$ & $3 \pm 0.5$ \\
\hline${ }^{\mathrm{w}} \mathrm{EF}, \mathrm{HDW}$ & $\mathrm{BD}^{\mathrm{a}}$ & $7 \pm 1.3$ & $5 \pm 0.8$ \\
\hline${ }^{\mathrm{d}} \mathrm{EF}, \mathrm{BH}$ & $2 \pm 1.6$ & $15 \pm 3.2$ & $8 \pm 3.3$ \\
\hline${ }^{\mathrm{d}} \mathrm{EF}, \mathrm{HDW}$ & $2 \pm 0.7$ & $8 \pm 0.2$ & $5 \pm 0.4$ \\
\hline${ }^{\mathrm{w}} \mathrm{YM}, \mathrm{BH}$ & $1 \pm 1.2$ & $3 \pm 0.3$ & $2 \pm 1.1$ \\
\hline${ }^{\mathrm{w}} \mathrm{YM}, \mathrm{HDW}$ & $2 \pm 1.2$ & $11 \pm 3.0$ & $5 \pm 2.2$ \\
\hline${ }^{\mathrm{d}} \mathrm{YM}, \mathrm{BH}$ & $1 \pm 0.3$ & $6 \pm 1.5$ & $2 \pm 0.6$ \\
\hline${ }^{\mathrm{d}}$ YM,HDW & $1 \pm 0.2$ & $10 \pm 4.6$ & $6 \pm 1.8$ \\
\hline${ }^{\mathrm{w}} \mathrm{IT}, \mathrm{BH}$ & $\mathrm{BD}^{\mathrm{a}}$ & $4 \pm 0.2$ & $2 \pm 0.9$ \\
\hline${ }^{\mathrm{w}} \mathrm{IT}, \mathrm{HDW}$ & $2 \pm 0.5$ & $11 \pm 1.6$ & $7 \pm 1.6$ \\
\hline${ }^{\mathrm{d}} \mathrm{IT}, \mathrm{BH}$ & $\mathrm{BD}^{\mathrm{a}}$ & $2 \pm 0.5$ & $2 \pm 0.2$ \\
\hline${ }^{\mathrm{d}} \mathrm{IT}, \mathrm{HDW}$ & $1 \pm 0.6$ & $11 \pm 2.0$ & $8 \pm 1.4$ \\
\hline${ }^{\mathrm{w}} \mathrm{LF}, \mathrm{BH}$ & $\mathrm{BD}^{\mathrm{a}}$ & $10 \pm 0.9$ & $7 \pm 1.3$ \\
\hline${ }^{\mathrm{w}} \mathrm{LF}, \mathrm{HDW}$ & $2 \pm 1.1$ & $65 \pm 1.6$ & $31 \pm 2.0$ \\
\hline${ }^{\mathrm{d}} \mathrm{LF}, \mathrm{BH}$ & $3 \pm 1.5$ & $12 \pm 4.3$ & $7 \pm 2.2$ \\
\hline${ }^{\mathrm{d}} \mathrm{LF}, \mathrm{HDW}$ & $2 \pm 1.6$ & $45 \pm 20.1$ & $22 \pm 10.8$ \\
\hline${ }^{\mathrm{w}} \mathrm{GRA}, \mathrm{BH}$ & $3 \pm 2.1$ & $3 \pm 1.1$ & $2 \pm 0.6$ \\
\hline${ }^{\mathrm{w}}$ GRA, HDW & $1 \pm 0.8$ & $18 \pm 2.1$ & $13 \pm 2.7$ \\
\hline${ }^{\mathrm{d}} \mathrm{GRA}, \mathrm{BH}$ & $1 \pm 0.8$ & $5 \pm 1.2$ & $4 \pm 1.6$ \\
\hline${ }^{\mathrm{d}}$ GRA, HDW & $2 \pm 1.2$ & $14 \pm 4.4$ & $7 \pm 0.9$ \\
\hline
\end{tabular}

While the minimum $\mathrm{Cl}^{-}$concentration of $2 \pm 0.5 \mathrm{mg} \mathrm{L}^{-1}$ was obtained from a bore-hole in IT district, during the dry season, the maximum of $65 \pm 1.6 \mathrm{mg} \mathrm{L}^{-1}$ was from a hand-drawn well in GRA district in the wet season. The small values of the standard deviation imply minor variability in the concentration of $\mathrm{Cl}^{-}$. The values of $\mathrm{Cl}^{-}$concentration obtained are below the stipulated maximum permissible limit of $250 \mathrm{mg}$ $\mathrm{L}^{-1}$ by the SON (2007). This indicates that chloride is of no health concern in groundwater of the study area. A previous study by Dahunsi et al. (2014) on some major cities in Ogun and Lagos States, Nigeria also reported low concentration of chloride of the range of 1.97-9.04 $\mathrm{mg} \mathrm{L}^{-1}$ for boreholes and wells showing that chloride may not be a major source of worry for groundwater used as drinking water in Nigeria. For wet and dry seasons, the mean concentrations of $\mathrm{NO}_{3}{ }^{-}$ obtained were 1 and $3 \mathrm{mg} \mathrm{L}^{-1}$ respectively, and are similar to values obtained for neighboring Ndokwa East, and Isoko North Local Government Areas of Delta State by Egboh and Emeshili (2008) and Owamah et al. (2013), respectively.

$\mathrm{NO}_{3}{ }^{-}$concentrations were significantly higher $(\mathrm{p}<$ 0.005) in the water samples of the hand drawn-wells than boreholes'. It also varied across the districts for the hand-drawn wells and boreholes. Though nitrate was not detected in the water samples of one handdrawn well and two boreholes from three different districts (Table 2), its concentration of (1-3 $\mathrm{mg} \mathrm{L}^{-1}$ ) in the rest other water samples is below the stipulated level of $50 \mathrm{mg} \mathrm{L}^{-1}$ set by SON (2007). There was no significant $(\mathrm{p}<0.05)$ variation of nitrate concentration among all the sampling locations and among the wells. For wet and dry seasons, the concentration of $\mathrm{SO}_{4}{ }^{2-}$ obtained ranged from 2 to 28 $\mathrm{mg} \mathrm{L}^{-1}$ with seasonal mean values of 10 and $7 \mathrm{mg} \mathrm{L}^{-1}$ for wet and dry seasons respectively. The observed seasonal mean variation is $3 \mathrm{mg} \mathrm{L}^{-1}$. Much higher values were obtained during the wet season and from hand-dug wells. Though sulfate is one of the least toxic anions, ingestion of excess sulfate could cause dehydration and laxative action (Dahunsi et al., 2014). Sulfate values in this study area are below the WHO (2006) and SON (2007) stipulated guidelines of $500 \mathrm{mg} \mathrm{L}^{-1}$ and $100 \mathrm{mg} \mathrm{L}^{-1}$ respectively (Table 5).

Metals: The mean concentrations of metals ( $\mathrm{Na}, \mathrm{K}$, $\mathrm{Mg}$ and $\mathrm{Ca}, \mathrm{Pb}, \mathrm{Cd}, \mathrm{Zn}, \mathrm{Cu}, \mathrm{Fe}$ and $\mathrm{Ba}$ ) detected in this study are shown in Table 3 . Na concentration range of $2,200 \pm 110$ to $72,100 \pm 13340 \mu \mathrm{g} \mathrm{L}^{-1}$ from this present study, is below the prescribed limit of 200,000 $\mu \mathrm{g} \mathrm{L}^{-1}$ set by the WHO (2006) and SON (2007) (Table 5) and hence not considered a contaminant. 
Table 5. Drinking water quality guidelines of the WHO and SON

\begin{tabular}{|c|c|c|c|}
\hline $\mathrm{S} / \mathrm{N}$ & Parameter & ${ }^{a}$ WHO (2006) & ${ }^{\mathrm{b}} \mathrm{SON}(2007)$ \\
\hline 1 & $\mathrm{pH}$ & $6.5-8.5$ & $6.5-8.5$ \\
\hline 2 & Cadmium $(\mathrm{Cd})$ & 0.003 & 0.003 \\
\hline 3 & Chloride $\left(\mathrm{Cl}^{-}\right)$ & - & 250 \\
\hline 4 & Chromium (Cr) & 0.050 & 0.050 \\
\hline 5 & Copper $(\mathrm{Cu})$ & 2.00 & 1.00 \\
\hline 6 & Iron $(\mathrm{Fe})$ & 0.30 & 0.30 \\
\hline 7 & Lead $(\mathrm{Pb})$ & ND1 & 0.01 \\
\hline 8 & Zinc (Zn) & - & 3.00 \\
\hline 9 & Nickel (Ni) & 0.020 & 0.02 \\
\hline 10 & Barium (Ba) & & \\
\hline 111 & Nitrate $\left(\mathrm{NO}_{3}^{-}\right)$ & 10 & 50.0 \\
\hline 12 & Nitrite $\left(\mathrm{NO}_{2}\right)$ & 1.0 & 0.2 \\
\hline 13 & Sulphate $\left(\mathrm{SO}_{4}{ }^{2-}\right)$ & 500 & 100 \\
\hline 14 & Total coliform (TC) & $0 \times 10^{2}$ & 10 \\
\hline 15 & E. coli count & $0 \times 10^{2}$ & - \\
\hline \multirow[t]{2}{*}{16} & Electrical & 1000 & 1000 \\
\hline & Conductivity $(\mathrm{EC})(\mu \mathrm{S} / \mathrm{cm})$ & & \\
\hline 17 & Total Suspended Solid (TSS) & - & - \\
\hline 18 & Total Solid (TS) & - & - \\
\hline 19 & Total Dissolved Solid (TDS) & 500 & 500 \\
\hline 20 & Salinity $(\%)$ & - & - \\
\hline 22 & Turbidity & 1 & 5 \\
\hline 22 & Magnesium $(\mathrm{Mg})$ & 200 & 0.2 \\
\hline 23 & Calcium $(\mathrm{Ca})$ & 200 & - \\
\hline 24 & Sodium $(\mathrm{Na})$ & 200 & 200 \\
\hline 25 & Potassium $(\mathrm{K})$ & 30 & - \\
\hline 26 & Dissolved Oxygen (DO) & 4 & 7.5 \\
\hline 27 & $\mathrm{BOD}_{5}$ & - & 6 \\
\hline 28 & Total Alkalinity (mg/L CaCO3) & - & - \\
\hline 29 & Hardness $((\mathrm{mg} / \mathrm{L} \mathrm{CaCO} 3)$ & 500 & 150 \\
\hline 30 & Colour apparent $(\mathrm{Hz})$ & 15 -apparent $(\mathrm{Hz})$ & 15 (TCU) \\
\hline
\end{tabular}

Notes: Apart from $\mathrm{pH}$ and parameters with indicated units, the unit of parameters is $\mathrm{mg} / \mathrm{L} *$ World Health Organization; ${ }^{b}$ Standard Organization of Nigeria. Sources: Adapted from Dahunsi et al. (2014) and Sojobi (2016) following minor adjustments

Apart from water samples of HDW in YM district with $\mathrm{Fe}$ concentration of $850 \pm 290 \mu \mathrm{g} \mathrm{L} \mathrm{L}^{-1}$, above the $300 \mu \mathrm{g} \mathrm{L}^{-1}$ of SON (2007), the rest other values of Fe obtained across the districts (Table 3 ) were below the specified maximum permissible level. High levels of $\mathrm{Fe}$ in water could lead to characteristic reddish staining and increased turbidity (Mkwate et al., 2017). The value of potassium obtained, is in line with the claim of Mkwate et al. (2017) that potassium concentration in natural waters has been widely reported to be low $\left(0-15,000 \mu \mathrm{g} \mathrm{L}^{-1}\right)$. Potassium levels obtained in this study are below the recommended limits of 25,000-50,000 $\mu \mathrm{g} \mathrm{L}^{-1}$ (Sojobi, 2016) for drinking water. From Table 3, the seasonal mean concentrations of $\mathrm{Na}, \mathrm{K}, \mathrm{Mg}$, and $\mathrm{Ca}$ are $17,700 \mu \mathrm{g}$ $\mathrm{L}^{-1}-15,300 \mu \mathrm{g} \mathrm{L}^{-1}, 12,100 \mu \mathrm{g} \mathrm{L}^{-1}-9,000 \mu \mathrm{g} \mathrm{L}^{-1}$, $11,000 \mu \mathrm{g} \mathrm{L}^{-1}-4,000 \mu \mathrm{g} \mathrm{L}^{-1}$ and $10,000 \mu \mathrm{g} \mathrm{L}^{-1}-$ $8,000 \mu \mathrm{g} \mathrm{L}^{-1}$ (wet -dry) respectively, indicating that the distribution of $\mathrm{Na}, \mathrm{K}, \mathrm{Mg}$, and $\mathrm{Ca}$ concentrations decreased from wet to dry season. These reported values in this study are within the acceptable WHO and SON limits (Table 5). The reason for the higher values of $\mathrm{Na}, \mathrm{K}, \mathrm{Mg}$, and $\mathrm{Ca}$ in the wet season could be attributed to the higher dissolution of rock containing the minerals of these metals during the rains. $\mathrm{Na}, \mathrm{K}, \mathrm{Mg}$ and $\mathrm{Ca}$ were also detected in the groundwater samples of selected communities in the
Isoko North Local Government Area, at lower than specified limits of the WHO and SON (Owamah et al., 2013).

The highest concentration of $\mathrm{Zn}\left(3410 \pm 1500 \mu \mathrm{g} \mathrm{L}^{-1}\right)$ was obtained in July from a hand-drawn well water sample in GRA district of the study area. The concentration of $\mathrm{Zn}$ ranged from $60 \pm 30 \mu \mathrm{g} \mathrm{L^{-1 }}$ to $3410 \pm 1500 \mu \mathrm{g} \mathrm{L}^{-1}$ and $60 \pm 10 \mu \mathrm{g} \mathrm{L}^{-1}$ to $2510 \pm 1300 \mu \mathrm{g}$ $\mathrm{L}^{-1}$ for the wet and dry seasons respectively. For the seasonal mean values of $\mathrm{Zn}, 1320 \mu \mathrm{g} \mathrm{L}^{-1}$ and $275 \mu \mathrm{g}$ $\mathrm{L}^{-1}$ were respectively obtained for wet and dry seasons. Only $\mathrm{Zn}$ of a HDW $\left(3410 \pm 1500 \mu \mathrm{g} \mathrm{L} \mathrm{L}^{-1}\right.$, wet season) and borehole $(3010 \pm 1400$, dry season) of GRA district surpassed the WHO (2006) and SON (2007) maximum acceptable limit of $3000 \mu \mathrm{g} \mathrm{\textrm {L } ^ { - 1 }}$. Zinc usually comes into the groundwater through the erosion of $\mathrm{Zn}$ containing rock and soil minerals. Zinc is majorly introduced into ground water by artificial pathways. Though $\mathrm{Zn}$ is an important nutrient for body growth and development, high levels of zinc can lead to nausea, vomiting and stomach cramps (Owamah et al., 2013). The maximum concentrations of $\mathrm{Pb}$ of $300 \pm 20 \mu \mathrm{g} \mathrm{L}^{-1}$ was obtained from a borehole in OER district in the month of December. The minimum concentration of $10 \mu \mathrm{g} \mathrm{L}^{-1}$ was obtained from borehole and hand-drawn well water samples 
from YM, IT, GRA and LF districts. Pb was detected in various water samples of the boreholes and handdrawn wells across the six representative districts. Seasonal average concentrations of $28 \mu \mathrm{g} \mathrm{L}^{-1}$ and 41 $\mu \mathrm{g} \mathrm{L}^{-1}$ for wet and dry seasons were respectively obtained. The concentration of Cd ranged from $10 \mu \mathrm{g}$ $\mathrm{L}^{-1}$ to $80 \mu \mathrm{g} \mathrm{L}^{-1}$ for both wet and dry seasons with mean concentrations of $20 \mu \mathrm{g} \mathrm{L}^{-1}$ for wet season and $10 \mu \mathrm{g} \mathrm{L}^{-1}$ for the dry season. The concentration of $\mathrm{Cu}$ ranged from $20 \pm 20 \mu \mathrm{g} \mathrm{L}^{-1}$ to $2110 \pm 700 \mu \mathrm{g} \mathrm{L}^{-1}$ in the wet season and from $10 \pm 20 \mu \mathrm{g} \mathrm{L}^{-1}$ to $1370 \pm 150 \mu \mathrm{g} \mathrm{L}$ ${ }^{1}$ in the dry season. The seasonal mean concentrations are $18 \mu \mathrm{g} \mathrm{L}^{-1}$ for wet season and $310 \mu \mathrm{g} \mathrm{L}^{-1}$ for dry season. Ba concentration ranged from $50 \pm 10 \mu \mathrm{g} \mathrm{L}^{-1}$ to $2510 \pm 440 \mu \mathrm{g} \mathrm{L}^{-1}$ in the wet season and from $40 \pm 20$ $\mu \mathrm{g} \mathrm{L}^{-1}$ to $1540 \pm 1540 \mu \mathrm{g} \mathrm{L}^{-1}$ in the dry season. The seasonal mean values for $\mathrm{Ba}$ are $1275 \mu \mathrm{g} \mathrm{L}^{-1}$ and 380 $\mu \mathrm{g} \mathrm{L}^{-1}$ for wet and dry seasons respectively.

Table 3. Mean values $\left(\mu \mathrm{g} \mathrm{L}^{-1}\right)$ of metals of groundwater samples from the study area for wet and dry seasons $(\mathrm{N}=18)$

\begin{tabular}{|c|c|c|c|c|c|c|c|c|c|c|}
\hline $\begin{array}{l}\text { Location/ } \\
\text { Water Source }\end{array}$ & $\mathrm{Pb}$ & $\mathrm{Cd}$ & $\mathrm{Zn}$ & $\mathrm{Cu}$ & $\mathrm{Fe}$ & $\mathrm{Ba}$ & $\mathrm{Na}$ & $\mathrm{K}$ & $\mathrm{Mg}$ & $\mathrm{Ca}$ \\
\hline${ }^{\mathrm{w}} \mathrm{OER}, \mathrm{BH}$ & $70 \pm 30$ & $30 \pm 20$ & $1900 \pm 120$ & $1500 \pm 80$ & $30 \pm 20$ & $1150 \pm 50$ & $5500 \pm 2220$ & $2600 \pm 1120$ & $5300 \pm 213$ & $8400 \pm 34$ \\
\hline${ }^{\mathrm{w}} \mathrm{OER}, \mathrm{HDW}$ & $60 \pm 20$ & $80 \pm 10$ & $2000 \pm 11$ & $2110 \pm 70$ & $20 \pm 20$ & $1700 \pm 14$ & $72100 \pm 133$ & $34800 \pm 205$ & $23600 \pm 14$ & $36700 \pm 17$ \\
\hline${ }^{\mathrm{d}} \mathrm{OER}, \mathrm{HDW}$ & $200 \pm 15$ & $80 \pm 14$ & $1900 \pm 10$ & $500 \pm 220$ & $160 \pm 1$ & $330 \pm 530$ & $35500 \pm 212$ & $5700 \pm 1060$ & $16500 \pm 29$ & $25200 \pm 50$ \\
\hline${ }^{\mathrm{w}} \mathrm{OEF}, \mathrm{BH}$ & $\mathrm{BD}^{\mathrm{a}}$ & $\mathrm{BD}^{\mathrm{a}}$ & $60 \pm 30$ & $20 \pm 20$ & $20 \pm 10$ & $1110 \pm 62$ & $23300 \pm 645$ & $5500 \pm 3060$ & $10800 \pm 69$ & $12300 \pm 65$ \\
\hline${ }^{\mathrm{w}} \mathrm{EF}, \mathrm{HDW}$ & $200 \pm 15$ & $60 \pm 10$ & $250 \pm 410$ & $350 \pm 15$ & $20 \pm 20$ & $1430 \pm 40$ & $14800 \pm 750$ & $8600 \pm 2570$ & $10300 \pm 37$ & $21000 \pm 27$ \\
\hline${ }^{\mathrm{d}} \mathrm{EF}, \mathrm{BH}$ & $\mathrm{BD}^{\mathrm{a}}$ & $\mathrm{BD}^{\mathrm{a}}$ & $500 \pm 10$ & $50 \pm 30$ & $30 \pm 10$ & $700 \pm 400$ & $17800 \pm 247$ & $7200 \pm 1050$ & $6300 \pm 148$ & $5800 \pm 118$ \\
\hline${ }^{\mathrm{d}} \mathrm{EF}$, HDW & $\mathrm{BD}^{\mathrm{a}}$ & $\mathrm{BD}^{\mathrm{a}}$ & $360 \pm 330$ & $50 \pm 80$ & $40 \pm 20$ & $650 \pm 780$ & $10700 \pm 202$ & $5700 \pm 1050$ & $5300 \pm 179$ & $6600 \pm 357$ \\
\hline${ }^{w}$ YM,BH & $190 \pm 24$ & $30 \pm 20$ & $1500 \pm 59$ & $490 \pm 42$ & $60 \pm 30$ & $900 \pm 550$ & $3800 \pm 750$ & $1600 \pm 530$ & $1900 \pm 770$ & $3400 \pm 112$ \\
\hline "YM, HDW & $50 \pm 10$ & $40 \pm 20$ & $1500 \pm 115$ & $900 \pm 50$ & $90 \pm 50$ & $1300 \pm 67$ & $13400 \pm 943$ & $7700 \pm 6690$ & $14300 \pm 15$ & $16200 \pm 98$ \\
\hline${ }^{\mathrm{d}} \mathrm{YM}, \mathrm{BH}$ & $10 \pm 20$ & $30 \pm 30$ & $1300 \pm 69$ & $120 \pm 10$ & $150 \pm 1$ & $70 \pm 110$ & $4800 \pm 920$ & $2100 \pm 6690$ & $2000 \pm 50$ & $2000 \pm 30$ \\
\hline${ }^{\mathrm{d}} \mathrm{YM}, \mathrm{HDW}$ & $30 \pm 30$ & $10 \pm 20$ & $1500 \pm 11$ & $670 \pm 34$ & $30 \pm 10$ & $250 \pm 660$ & $10900 \pm 654$ & $3800 \pm 1840$ & $7200 \pm 255$ & $7000 \pm 212$ \\
\hline${ }^{\mathrm{w}} \mathrm{IT}, \mathrm{BH}$ & $10 \pm 10$ & $\mathrm{BD}^{\mathrm{a}}$ & $80 \pm 10$ & $50 \pm 10$ & $\mathrm{BD}^{\mathrm{a}}$ & $50 \pm 10$ & $5100 \pm 200$ & $2500 \pm 670$ & $2300 \pm 830$ & $3300 \pm 900$ \\
\hline${ }^{\mathrm{w}} \mathrm{IT}, \mathrm{HDW}$ & $30 \pm 10$ & $10 \pm 10$ & $1770 \pm 11$ & $600 \pm 30$ & $230 \pm 2$ & $1300 \pm 20$ & $19900 \pm 620$ & $9700 \pm 3010$ & $9500 \pm 472$ & $10800 \pm 45$ \\
\hline${ }^{\mathrm{d}} \mathrm{IT}, \mathrm{BH}$ & $10 \pm 10$ & $\mathrm{BD}^{\mathrm{a}}$ & $60 \pm 10$ & $90 \pm 80$ & $30 \pm 10$ & $40 \pm 20$ & $4200 \pm 600$ & $1700 \pm 250$ & $2700 \pm 100$ & $1500 \pm 114$ \\
\hline${ }^{\mathrm{w}} \mathrm{LF}, \mathrm{BH}$ & $10 \pm 10$ & $\mathrm{BD}^{\mathrm{a}}$ & $70 \pm 30$ & $50 \pm 10$ & $40 \pm 20$ & $700 \pm 500$ & $12600 \pm 280$ & $4400 \pm 2250$ & $5100 \pm 140$ & $6200 \pm 166$ \\
\hline${ }^{\mathrm{w}} \mathrm{LF}, \mathrm{HDW}$ & $\mathrm{BD}^{\mathrm{a}}$ & $\mathrm{BD}^{\mathrm{a}}$ & $1170 \pm 69$ & $1300 \pm 13$ & $30 \pm 10$ & $2510 \pm 44$ & $52400 \pm 167$ & $25700 \pm 717$ & $25800 \pm 85$ & $28800 \pm 78$ \\
\hline${ }^{\mathrm{d}} \mathrm{LF}, \mathrm{BH}$ & $\mathrm{BD}^{\mathrm{a}}$ & $10 \pm 10$ & $60 \pm 10$ & $10 \pm 20$ & $30 \pm 10$ & $870 \pm 976$ & $8600 \pm 860$ & $4400 \pm 980$ & $5600 \pm 181$ & $7600 \pm 165$ \\
\hline${ }^{\mathrm{d}} \mathrm{LF}, \mathrm{HDW}$ & $10 \pm 10$ & $10 \pm 0$ & $1170 \pm 69$ & $360 \pm 400$ & $20 \pm 10$ & $1540 \pm 15$ & $32800 \pm 112$ & $13600 \pm 429$ & $16100 \pm 60$ & $18600 \pm 16$ \\
\hline${ }^{\mathrm{w}} \mathrm{GRA}, \mathrm{BH}$ & $\mathrm{BD}^{\mathrm{a}}$ & $10 \pm 10$ & $3010 \pm 14$ & $1800 \pm 60$ & $50 \pm 20$ & $1900 \pm 15$ & $3400 \pm 700$ & $1800 \pm 690$ & $4000 \pm 201$ & $6300 \pm 330$ \\
\hline${ }^{\mathrm{w}} \mathrm{GRA}, \mathrm{HDW}$ & $15 \pm 10$ & $30 \pm 10$ & $3410 \pm 15$ & $1100 \pm 10$ & $30 \pm 10$ & $2350 \pm 78$ & $25100 \pm 55$ & $18600 \pm 121$ & $13000 \pm 44$ & $16100 \pm 76$ \\
\hline${ }^{\mathrm{d}} \mathrm{GRA}, \mathrm{BH}$ & $\mathrm{BD}^{\mathrm{a}}$ & $20 \pm 12$ & $2110 \pm 15$ & $380 \pm 300$ & $200 \pm 2$ & $440 \pm 330$ & $6100 \pm 235$ & $4000 \pm 1140$ & $5500 \pm 215$ & $1800 \pm 880$ \\
\hline${ }^{\mathrm{d}}$ GRA, HDW & $45 \pm 11$ & $\mathrm{BD}^{\mathrm{a}}$ & $2510 \pm 13$ & $1370 \pm 15$ & $150 \pm 1$ & $80 \pm 70$ & $22800 \pm 11$ & $10400 \pm 630$ & $5000 \pm 125$ & $3900 \pm 300$ \\
\hline
\end{tabular}

Results are expressed as mean \pm standard deviation; ${ }^{w}=$ wet season; $\quad{ }^{d}=$ dry season; $a=b e l o w$ detection limits.

Apart from $\mathrm{Pb}$ and $\mathrm{Cd}$, the seasonal mean concentrations of the other metals found in the groundwater of the selected districts were below the WHO (2006) and SON (2007) stipulated limits for potable water (Table 5). Using ANOVA, no significant difference $(\mathrm{P}<0.005)$ in the values of metals for hand-drawn well and bore-hole water samples was obtained. The presence of slightly elevated levels of lead in a few samples in the study area could be as a result of the various oil explorations and processing activities within the subregion and careless disposal of various forms of electronic wastes and spent batteries on the soil (Owamah et al., 2013). The community also houses a flow station. According to Owamah et al. (2013), exposure to high levels of $\mathrm{Pb}$ can cause damage to the kidney and brain, and sometimes, make pregnant women to miscarry. Reports also show that elevated levels of $\mathrm{Pb}$ in kids could cause convulsion and neurological damages (USEPA 1991; Khan et al. 2013). In men, high concentration of lead can damage reproductive organs. $\mathrm{Cd}$ and its various compounds are reportedly, carcinogenic (Dahunsi et al., 2014; Khan et al., 2013). At high levels of exposure, Cd can cause vomiting and diarrhea but lower levels for longer period, can cause kidney impairment (USEPA 1977, Mkwate et al., 2017). Other health challenges associated with drinking water containing high levels of $\mathrm{Pb}$ and $\mathrm{Cd}$ are contained in Sojobi (2016).

Conclusion: Groundwater in the community was found to be slightly polluted with metals of $\mathrm{Pb}$ and $\mathrm{Ca}$, and with coliform bacteria. Samples from the hand-dug wells were noted to have higher values of these contaminants. Bacteria contamination was attributed to the poor disposal of solid waste (open dumps) and sewage, and the location of bore holes and hand-drawn wells close to pit-latrines and septic tanks. The slight metals contamination was linked to oil explorations and processing activities within the area of study and improper disposal of electronic wastes. While the concerned agencies and authorities should consider providing potable water for the people very important, household water treatment is 
recommended in the interim for the residents of the community.

Acknowledgements: The author appreciates the financial and technical support of the Academic Research and Entrepreneurship Development Initiative, Nigeria and its Vice-President (Mr Samuel Ilabor, a Chemist). The undergraduate students of the Department of Civil Engineering, Delta State University, Nigeria are also acknowledged for their roles in data collection.

\section{REFERENCES}

Ademoroti, CMA (1996). Environmental Chemistry and Toxicology. Ibadan: Foludex Press Ltd. APHA (1992). "Standard Methods for Examination of Water and Waste-water"; 18th Edition, Washington DC: American Public Health Association.

APHA (2012). "Standard Methods for Examination of Water and Waste-water"; 22nd Edition, Washington DC: American Public Health Association.

Dahunsi, S O; Owamah, H I; Ayandiran, T A; Oranusi, U S (2014). Drinking water quality and public health of selected communities in South Western Nigeria. Wat. Qual. Exp. Heal. 6, 143153.

Egboh, SHO; Emeshili, EM (2008). The fluoride content of drinking water samples from Ndokwa Area, South-South Nigeria. J. Chem. Soc. Nig. 33(2): 54-61.

Khan, S; Shahnaz, M; Jehai, N; Rehman, S; Shah, M T; Din, S (2013). Drinking water quality and human health risk in Charsadda district, Pakistan. J. Cleaner Prod. 60:93-101.

LENNTECH (2016). Water Conductivity. Available on. http://www.lenntech.com/ applications/ultrapure/conductivity/waterconductivity.htm.
Mkwate , R C; Chidya, RCG; Wanda, EMM (2017). Assessment of drinking water quality and rural household water treatment in Balaka District, Malawi. Phys. Chem. Earth 100:353-362.

National Population Commission of Nigeria (NPC). http://www.informationng.com/tag/nationalpopulation-commission. Accessed on the $25^{\text {th }}$ of December, 2018 at 14.22 Nigerian time.

Owamah, IH, Asiagwu, AK, Egboh, SHO; PhilUsiayo, S (2013). Drinking water quality at Isoko North communities of the Niger Delta Region, Nigeria Toxi. Environ. Chem. 95(7), 1116-1128.

Sojobi, SO (2016). Evaluation of groundwater quality in a rural community in North Central of Nigeria. Environ Monit Assess. 188:192.

SON (2007). Standard Organization of Nigeria. Nigerian Standard for Drinking Water Quality, Nigeria, NIS 554: 2007.

USEPA (1977). "Toxicology of metals in: Environmental Health Effects Research Series"; Vol. II, Washington, DC: United States Environmental Protection Agency.

USEPA (1991). "Lead in drinking water; Public Education, National Primary Drinking Water Regulations, Control of Lead and Copper"; 40CFR Part 141.85 Federal Register: United States Environmental Protection Agency.

WHO (2006). "Guidelines for Drinking Water Quality", $3^{\text {rd }}$ Edition, Vol. I Recommendations. First addendum to $3^{\text {rd }}$ Edition, Geneva: World Health Organization.

WHO (2012). World Health Organization (WHO). Global Burden of Disease. WHO Press, Geneva, Switzerland. 